\title{
Chemoselective synthesis of diaryl disulfides via a visible light-mediated coupling of arenediazonium tetrafluoroborates and $\mathrm{CS}_{2}$
}

\author{
Jing Leng, Shi-Meng Wang and Hua-Li Qin*
}

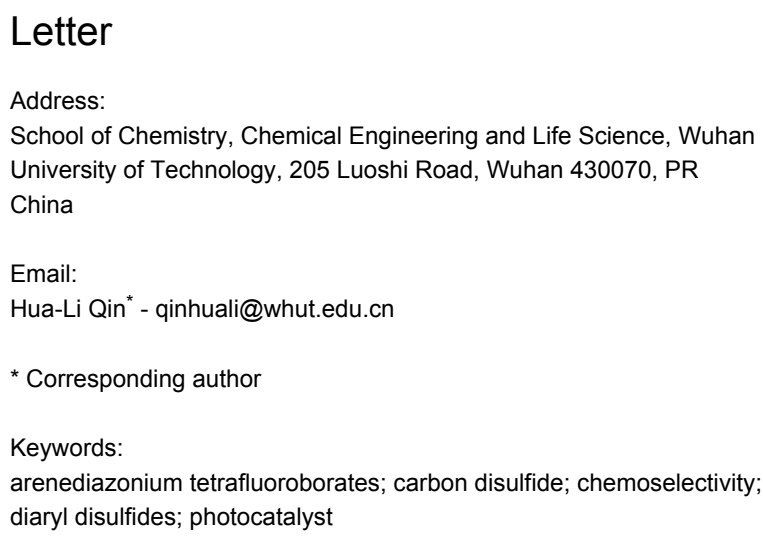

Beilstein J. Org. Chem. 2017, 13, 903-909. doi:10.3762/bjoc. 13.91

Received: 11 January 2017

Accepted: 25 April 2017

Published: 15 May 2017

Associate Editor: J. A. Murphy

(ㄷ) 2017 Leng et al.; licensee Beilstein-Institut. License and terms: see end of document.

\begin{abstract}
A highly efficient and chemoselective method for the synthesis of diaryl disulfides is developed via a visible light-promoted coupling of readily accessible arenediazonium tetrafluoroborates and $\mathrm{CS}_{2}$. This practical and convenient protocol provides a direct pathway for the assembly of a series of disulfides in an environmentally friendly manner with good to excellent yields.
\end{abstract}

\section{Findings}

The development of methods for the functionalization of peptides and proteins under mild conditions is a current frontier in the fields of chemistry, biology and drug discovery [1-4]. Most of the pharmaceutically relevant proteins contain disulfide bonds, furthermore, the disulfide ligation and its established chemoselectivity is of great advantage for proteins' functionalization [5]. In addition, disulfides also play valuable roles as versatile building blocks for industrial applications [6-8]. Thus, the development of methodologies for the synthesis of disulfides is rather desirable and many research groups have made great contributions to the synthesis of diaryl disulfides such as the Chandrasekaran group [9] and the Wacharasindhu group [10]. Indeed, the design of sustainable and useful transformations with applications in industry is considered of high practical value. In this context, carbon disulfide, a cheap and abundant chemical, has been widely used as reactant and solvent in both industry and materials science. For example, Batanero and co-workers reported an electrochemical transformation of carbon disulfide into diaryl disulfides [11]. Sunlight as abundant and almost infinitely available energy resource has been widely used for chemical transformations in the sense of cost, safety, availability, and environmental friendliness [1215]. Herein, we report a visible light-mediated coupling of arenediazonium tetrafluoroborates and $\mathrm{CS}_{2}$ for the chemoselective assembly of diaryl disulfides as our continuing endeavor of utilizing arenediazonium tetrafluoroborates [16] for synthetic applications (Scheme 1).

We conducted our initial study with benzenediazonium tetrafluoroborate (1a) and $\mathrm{CS}_{2}(\mathbf{2})$ as model substrates to examine 
<smiles>[R]c1cccc(Sc2cccc([R])c2)c1</smiles>

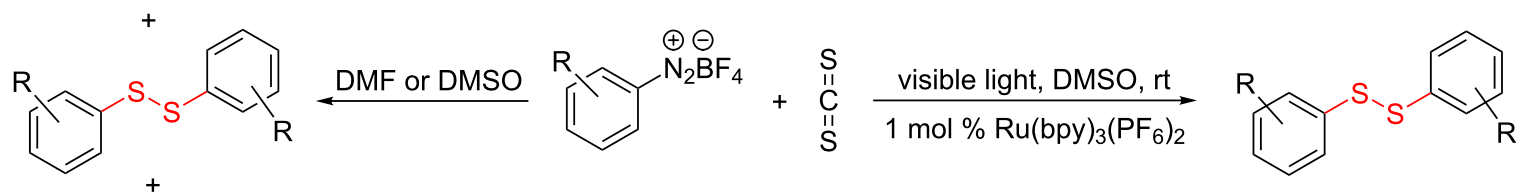<smiles>[R]c1cccc(S[AsH]c2cccc([R])c2)c1</smiles>

high selectivity

Scheme 1: Chemoselective assembly of diaryl disulfides.

the feasibility of the formation of diphenyl disulfide (3a) (Table 1). Various solvents were screened and to our delight, it was found that the reaction of $\mathbf{1 a}$ and $\mathbf{2}$ in DMF and DMSO gave the desired product in a moderate yield of $54 \%$ and $53 \%$, respectively (Table 1, entries 7 and 8 ). Unfortunately, under the applied conditions, the chemoselectivity of the reaction was poor, affording a mixture of unexpected diphenyl sulfide (4a) and diphenyl polysulfides (5a) as byproducts. Thus, a study to optimize the reaction conditions with regard to chemoselectivity and to minimize the formation of the byproducts was conducted.

As recently surveyed, photoredox catalysts are widely employed for the generation of radicals for diverse radical reactions [19]. Further, the application of aryl radicals generated from aryldiazonium salts under visible light irradiation has also been studied $[14,15]$ by taking advantage of visible light as abundant and environmentally friendly energy source for organic syntheses. The photochemistry of diazonium salts has been widely studied since the early 19th century, at which time, it was noticed that benzenediazonium nitrate turns red upon exposure to sunlight due to decomposition and formation of radical species [20]. Subsequently, the photodecomposition of diazonium salts by loss of nitrogen upon exposure to light has been utilized in organic synthesis for example to remove amino groups from anilines [21] or for arylation reactions [15,22].

Based on the above research results, we envisioned that a radical pathway may facilitate the formation of diaryl disulfides. Therefore the photocatalyst $\mathrm{Ru}(\mathrm{bpy})_{3}\left(\mathrm{PF}_{6}\right)_{2}$ (bpy $=2,2^{\prime}-$

Table 1: Solvent screening for the coupling of benzenediazonium tetrafluoroborate (1a) and $\mathrm{CS}_{2}(2){ }^{a}$

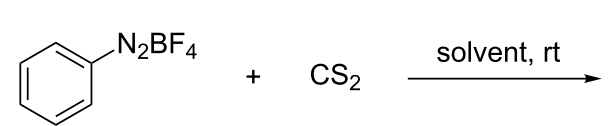

$1 \mathbf{a}$

2

\begin{tabular}{lllll}
\hline Entry & Solvents & Yield 3a (\%) & Yield 4a (\%) & Yield 5a $(\%)^{b}$ \\
1 & MeOH & n.d. & n.d. & n.d. \\
2 & THF & 36 & 5 & n.d. \\
3 & dioxane & n.d. & n.d. & 14 \\
4 & acetone & n.d. & n.d. & n.d. \\
5 & DCM & n.d. & n.d. & 31 \\
6 & acetonitrile & n.d. & 3 & 27 \\
8 & DMF & 54 & 3 & 24 \\
\hline
\end{tabular}

aReaction conditions: $\mathbf{1 a}(0.1 \mathrm{mmol}), \mathbf{2}(0.2 \mathrm{mmol})$, solvent $(2 \mathrm{~mL}), \mathrm{rt}, 6 \mathrm{~h}$; byields were determined by HPLC using $3 \mathbf{a}$ and $\mathbf{4 a}$ as the external standards; the yield of $\mathbf{5 a}$ is based on the integration of the corresponding HPLC peaks $[17,18]$; $n . d .=$ not determined. 
bipyridine) [23] and a $20 \mathrm{~W}$ blue-light LED were chosen as catalyst and the source of visible light, respectively for our model reaction (Table 2). A variety of solvents was evaluated and eventually, it was found that the coupling of benzenediazonium tetrafluoroborate (1a) and $\mathrm{CS}_{2}(\mathbf{2})$ in ethanol as the solvent gave the desired product diphenyl disulfide (3a) in $77 \%$ yield accompanied by only $8 \%$ of the undesired diphenyl polysulfides (Table 2, entry 4). Switching to DMSO as the solvent for the reaction afforded exclusively the desired product $\mathbf{3 a}$ in excellent yield (88\%, Table 2, entry 6). Next, other sulfur sources were also examined, such as $\mathrm{S}_{8}, \mathrm{NaSH}, \mathrm{Na}_{2} \mathrm{~S}, \mathrm{Na}_{2} \mathrm{~S}_{2} \mathrm{O}_{3}$, $\mathrm{Na}_{2} \mathrm{~S}_{2} \mathrm{O}_{4}$ and $\mathrm{K}_{2} \mathrm{~S}_{2} \mathrm{O}_{8}$, however, none of them provided the desired product in an acceptable yield (Table 2, entries 7-13).

In order to maximize the yields, varying amounts of $\mathrm{CS}_{2}$ (2) were also tested (Table 3) and it was found that the $\mathrm{CS}_{2}$ loading had a considerable influence on the reaction. By decreasing the loading of $\mathrm{CS}_{2}$ from 2 equiv to 0.5 equiv, the yield of the product 3a dropped to $42 \%$, whereas increasing amounts of $\mathrm{CS}_{2} \mathrm{did}$ not significantly increase the yield of the product. Subsequently, different photocatalysts were investigated and it turned out that the choice of catalyst also had a significant impact on our model reaction. $\mathrm{Ru}$ (bpy) ${ }_{3} \mathrm{Cl}_{2}$ catalyzed this coupling to afford the desired product 3a in a moderate yield of $65 \%$ (Table 3, entry
8). However, when the iridium-based photocatalysts $\operatorname{Ir}(\mathrm{ppy})_{3}$ [24], $\left[\operatorname{Ir}(\text { ppy })_{2}(\right.$ bpy) $] \mathrm{PF}_{6}$ and $\left[\operatorname{Ir}(\text { ppy })_{2}(\mathrm{dtbbpy})\right] \mathrm{PF}_{6}\left(\mathrm{bpy}=2,2^{\prime}-\right.$ bipyridine, ppy $=2$-phenylpyridine, dtbbpy $=4,4$ '-di-tert-butyl2,2 '-bipyridine) $[25,26]$ were used, the product yield of diphenyl disulfide (3a) was much lower compared to reactions performed in the presence of ruthenium catalysts (Table 3, entries 9-11).

A plausible reaction mechanism has been proposed and is depicted in Scheme 2. We envision that the phenyl radical I was initially generated under visible light irradiation [14,15]. Subsequently, the radical I attacked the sulfur atom of carbon disulfide to provide the intermediate II which can be converted to radical intermediate III through the cleavage of the carbon-sulfur bond accompanied with the release of a carbon sulfide [11]. The active radical intermediate III can transform into three types of products through different pathways. Firstly, diaryl disulfide 3 is obtained through a dimerization of radical intermediates III, whereas the reaction of radical III with phenyl radical I is leading to byproduct 4. Finally, radical III can react with various equivalents of $\mathrm{CS}_{2}$ with release of carbon sulfide to generate aryl-polythio radicals IV and V. The combination of the latter intermediates with radical $\mathbf{I}$ then finally affords polysulfides $\mathbf{5}$.

Table 2: Screening of the solvents and sulfur sources for the visible light-mediated coupling of benzenediazonium tetrafluoroborate (1a) and $\mathrm{CS}_{2}(\mathbf{2})$ and other sulfur sources in the presence of $\mathrm{Ru}(\mathrm{bpy})_{3}\left(\mathrm{PF}_{6}\right)_{2}$ as the photocatalyst. ${ }^{\mathrm{a}}$

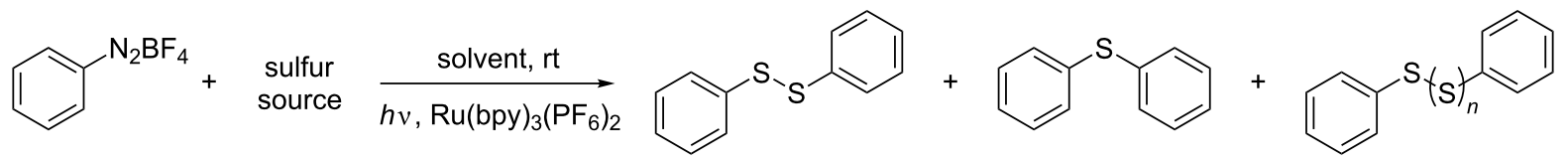

$1 \mathrm{a}$

$3 a$

$4 a$

$5 \mathbf{a}$

\begin{tabular}{|c|c|c|c|c|c|}
\hline Entry & Solvent & Sulfur source & Yield $3 \mathbf{a}(\%)^{\mathrm{b}}$ & Yield 4a $(\%)^{b}$ & Yield $\mathbf{5 a}(\%)^{\mathrm{b}}$ \\
\hline 1 & $\mathrm{MeOH}$ & $\mathrm{CS}_{2}$ & 88 & $<1$ & 10 \\
\hline 2 & $\mathrm{H}_{2} \mathrm{O}$ & $\mathrm{CS}_{2}$ & 47 & 5 & 20 \\
\hline 3 & THF & $\mathrm{CS}_{2}$ & 87 & $<1$ & 8 \\
\hline 4 & $\mathrm{EtOH}$ & $\mathrm{CS}_{2}$ & 77 & n.d. & 8 \\
\hline 5 & acetone & $\mathrm{CS}_{2}$ & 79 & 7 & 3 \\
\hline 6 & DMSO & $\mathrm{CS}_{2}$ & 88 & n.d. & $<1$ \\
\hline 7 & DMSO & $\mathrm{S}_{8}$ & 14 & 9 & 67 \\
\hline 8 & DMSO & $\mathrm{Na}_{2} \mathrm{~S}$ & n.d. & 43 & 11 \\
\hline 9 & DMSO & $\mathrm{Na}_{2} \mathrm{~S}_{2} \mathrm{O}_{3}$ & n.d. & n.d. & n.d. \\
\hline 10 & DMSO & $\mathrm{Na}_{2} \mathrm{~S}_{2} \mathrm{O}_{4}$ & n.d. & n.d. & n.d. \\
\hline 11 & DMSO & $\mathrm{K}_{2} \mathrm{~S}_{2} \mathrm{O}_{8}$ & n.d. & n.d. & 4 \\
\hline 12 & DMSO & $\mathrm{NaSH}$ & 22 & 28 & 14 \\
\hline 13 & DMSO & $\left(\mathrm{NH}_{4}\right)_{2} \mathrm{~S}_{2} \mathrm{O}_{8}$ & n.d. & n.d. & 4 \\
\hline
\end{tabular}

${ }^{a}$ Reaction conditions: $1 \mathrm{a}(0.1 \mathrm{mmol})$, sulfur sources $(0.2 \mathrm{mmol}), \mathrm{Ru}(\mathrm{bpy})_{3}\left(\mathrm{PF}_{6}\right)_{2}(0.001 \mathrm{mmol})$, blue light $(20 \mathrm{~W})$, solvents $(2 \mathrm{~mL})$, rt, $6 \mathrm{~h}$; ${ }^{b}$ yields were determined by HPLC using $\mathbf{3} \mathbf{a}$ and $\mathbf{4 a}$ as the external standards, the yield of $\mathbf{5 a}$ is based on the integration of the corresponding HPLC peaks [17,18]; n.d. $=$ not determined. 
Table 3: Screening of photocatalysts for the visible light-mediated coupling of benzenediazonium tetrafluoroborate (1a) and $\mathrm{CS}_{2}(\mathbf{2}){ }^{\mathrm{a}}$

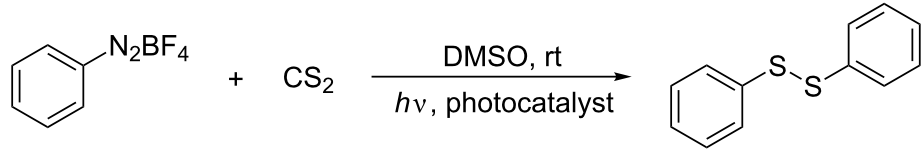

$1 \mathrm{a}$

2

3a

\begin{tabular}{lllll}
\hline Entry & $\mathbf{2}$ (equiv) & photocatalyst & solvent & Yield 3a $(\%)^{\mathrm{b}}$ \\
\hline 1 & 0.5 & $\mathrm{Ru}(\mathrm{bpy})_{3}\left(\mathrm{PF}_{6}\right)_{2}$ & $\mathrm{DMSO}$ & 42 \\
2 & 1 & $\mathrm{Ru}(\mathrm{bpy})_{3}\left(\mathrm{PF}_{6}\right)_{2}$ & $\mathrm{DMSO}$ & 47 \\
3 & 1.5 & $\mathrm{Ru}(\mathrm{bpy})_{3}\left(\mathrm{PF}_{6}\right)_{2}$ & $\mathrm{DMSO}$ & 53 \\
4 & 2 & $\mathrm{Ru}(\mathrm{bpy})_{3}\left(\mathrm{PF}_{6}\right)_{2}$ & $\mathrm{DMSO}$ & 88 \\
5 & 2.5 & $\mathrm{Ru}(\mathrm{bpy})_{3}\left(\mathrm{PF}_{6}\right)_{2}$ & $\mathrm{DMSO}$ & 55 \\
6 & 3 & $\mathrm{Ru}(\mathrm{bpy})_{3}\left(\mathrm{PF}_{6}\right)_{2}$ & $\mathrm{DMSO}$ & 57 \\
7 & - & $\mathrm{Ru}(\mathrm{bpy})_{3}\left(\mathrm{PF}_{6}\right)_{2}$ & $\mathrm{CS}_{2}$ & $\mathrm{n} . \mathrm{d}$. \\
8 & 2 & $\mathrm{Ru}(\mathrm{bpy})_{3} \mathrm{Cl}_{2}$ & $\mathrm{DMSO}$ & 65 \\
9 & 2 & $\operatorname{Ir}(\mathrm{ppy})_{3}$ & $\mathrm{DMSO}$ & 57 \\
10 & 2 & $\operatorname{Ir}(\mathrm{ppy})_{2}(\mathrm{bpy})\left(\mathrm{PF}_{6}\right)$ & $\mathrm{DMSO}$ & 73 \\
11 & 2 & $\operatorname{Ir}(\mathrm{ppy})_{2}(\mathrm{dtbbpy})\left(\mathrm{PF}_{6}\right)$ & $\mathrm{DMSO}$ & 8 \\
12 & 2 & $\operatorname{none}$ & $\mathrm{DMSO}$ & 53 \\
\hline
\end{tabular}

aReaction conditions: $1 \mathrm{a}(0.1 \mathrm{mmol})$, photocatalyst $(0.001 \mathrm{mmol})$, blue light $(20 \mathrm{~W})$, solvent $(2 \mathrm{~mL})$, rt, $6 \mathrm{~h}$; byields were determined by HPLC using $3 \mathrm{a}$ as the external standard.

$$
\begin{aligned}
& \text { ArSAr } \\
& 4 \\
& \operatorname{Ar}^{\circ} \jmath_{1}
\end{aligned}
$$

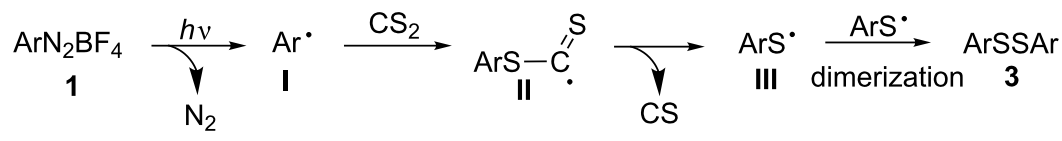

$$
\begin{aligned}
& \mathrm{cs}_{2}-\mathrm{cs}
\end{aligned}
$$

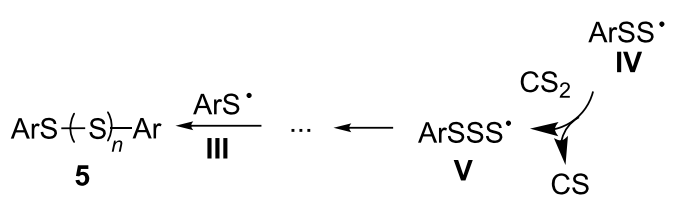

Scheme 2: A plausible reaction mechanism.

To demonstrate the scope of the reaction, a series of arenediazonium tetrafluoroborates was utilized in the reaction with $\mathrm{CS}_{2}$ to generate the corresponding diaryl disulfides (Table 4). Arenediazonium tetrafluoroborates $\mathbf{1 b}-\mathbf{p}$ with both, electronwithdrawing and donating groups successfully underwent transformation, affording the corresponding coupling products $\mathbf{3 b}-\mathbf{p}$ in good to excellent yields (42-99\%). Also sterically demanding substrates gave the desired products in good yields (3d, 3f, 3g, 3i, 3m and 3n) and functional groups such as chloro, bromo, ester, methyl, nitro, and phenyl groups were also compatible with the reaction conditions.

\section{Conclusion}

In conclusion, we have developed an efficient method for the synthesis of diaryl disulfides through the coupling of arenediazonium tetrafluoroborates and $\mathrm{CS}_{2}$. This straightforward 
Table 4: Reaction scope of the visible light-mediated coupling of arenediazonium tetrafluoroborates 1 with $\mathrm{CS}_{2}(2)$.

$$
\begin{aligned}
& \text { 致 } \\
& \text { 1a-p } 23 a-p
\end{aligned}
$$

\begin{tabular}{|c|c|c|c|}
\hline Substrate $1^{a}$ & Product 3 , yield ${ }^{b}$ & Substrate $1^{a}$ & Product 3 , yield $b$ \\
\hline
\end{tabular}<smiles>[123I-]Nc1ccccc1</smiles>

1a

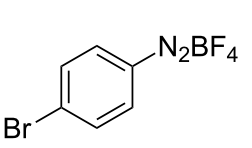

1b

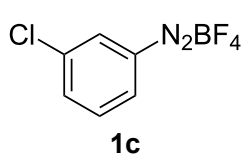<smiles>FC(Br)(Br)Nc1ccccc1Cl</smiles>

1d

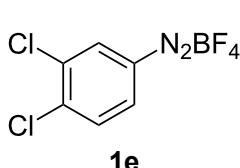<smiles>FC(F)(Br)Nc1c(Br)cc(Br)cc1Br</smiles><smiles>Cc1c(NC(F)(F)Br)cccc1[N+](=O)[O-]</smiles>

$1 \mathrm{~g}$<smiles>c1ccc(SSc2ccccc2)cc1</smiles>

3a, $80 \%, 50 \%$ c<smiles>Brc1ccc(SSc2ccc(Br)cc2)cc1</smiles>

3b, $81 \%, 78 \%$ c<smiles>Clc1cccc(SSc2cccc(Cl)c2)c1</smiles>

3c, $85 \%, 72 \%^{\mathrm{c}}$<smiles>Clc1ccccc1SSc1ccccc1Cl</smiles>

3d, $94 \%$<smiles>Clc1ccc(SSc2ccc(Cl)c(Cl)c2)cc1Cl</smiles>

3e, $90 \%$<smiles>Brc1cc(Br)c(SSc2c(Br)cc(Br)cc2Br)c(Br)c1</smiles>

$$
\text { 3f, } 88 \%
$$<smiles>Cc1c(SSc2cccc([N+](=O)[O-])c2C)cccc1[N+](=O)[O-]</smiles>

3g, $88 \%$<smiles>CC(=O)c1ccccc1N(Br)Br</smiles>

1i<smiles>O=[N+]([O-])c1ccc([Mg][18F])c(Cl)c1</smiles>

1j<smiles>[Pb]Nc1ccc(Oc2ccccc2)cc1</smiles>

$1 k$<smiles>Cc1cccc(N)c1C</smiles>

11<smiles>Cc1cc(C)c(NC(F)(F)Br)c(C)c1</smiles><smiles>Cc1cccc(C)c1NC(Br)Br</smiles>

$1 n$<smiles>Cc1cc(C)cc(N(Br)Br)c1</smiles>

10<smiles>COC(=O)c1ccccc1SSc1ccccc1C(C)=O</smiles>

3i, $94 \%, 82 \%^{\mathrm{c}}$<smiles>O=[N+]([O-])c1ccc(SSc2ccc([N+](=O)[O-])cc2Cl)c(Cl)c1</smiles>

3j, $99 \%, 85 \%^{\mathrm{c}}$<smiles>c1ccc(Oc2ccc(SSc3ccc(Oc4ccccc4)cc3)cc2)cc1</smiles>

3k, $70 \%$<smiles>Cc1cccc(SSc2cccc(C)c2C)c1C</smiles>

3I, $76 \%$<smiles>Cc1cc(C)c(SSc2c(C)cc(C)cc2C)c(C)c1</smiles>

$3 \mathrm{~m}, 56 \%$<smiles>Cc1cccc(C)c1SSc1c(C)cccc1C</smiles>

3n, $42 \%$<smiles>Cc1cc(C)cc(SSc2cc(C)cc(C)c2)c1</smiles>

3o, $56 \%$ 
Table 4: Reaction scope of the visible light-mediated coupling of arenediazonium tetrafluoroborates 1 with $\mathrm{CS}_{2}$ (2). (continued)<smiles>BrN(c1ccccc1)c1ccccc1</smiles>

$1 \mathrm{~h}$<smiles>c1ccc(-c2ccc(SSc3ccc(-c4ccccc4)cc3)cc2)cc1</smiles>

$3 \mathrm{~h}, 76 \%$<smiles>CCOC(=O)c1ccc(N(Br)c2ccccc2)cc1</smiles>

$1 \mathrm{p}$<smiles>CCOC(=O)c1ccc(SSc2ccc(C(=O)OCC)cc2)cc1</smiles>

3 p, $90 \%{ }^{c}, 92 \%$ c,d

aReaction conditions: $1(0.1 \mathrm{mmol}), \mathrm{CS}_{2}(0.2 \mathrm{mmol}), \mathrm{Ru}(\mathrm{bpy})_{3}\left(\mathrm{PF}_{6}\right)_{2}(0.001 \mathrm{mmol})$, blue light $(20 \mathrm{~W})$, DMSO $(2 \mathrm{~mL})$, rt, $6 \mathrm{~h}$; bisolated yields after chromatography on silica gel; cthe reactions were carried out with the diazonium salts 1 at a $5 \mathrm{mmol}$ scale; dacetone was used as the solvent.

visible light-promoted process proceeds under mild reaction conditions and is applicable for the assembly of a wide range of diaryl disulfides. Further studies to clearly understand the reaction mechanism and the synthetic applications are ongoing in our laboratory.

\section{Supporting Information}

\section{Supporting Information File 1}

Experimental procedures, characterization data and copies of ${ }^{1} \mathrm{H}$ and ${ }^{13} \mathrm{C}$ NMR spectra for final compounds. [http://www.beilstein-journals.org/bjoc/content/ supplementary/1860-5397-13-91-S1.pdf]

\section{Acknowledgements}

This work was supported by the Wuhan University of Technology.

\section{References}

1. Bode, J. W. Curr. Opin. Drug Discovery Dev. 2006, 9, 765-775.

2. Pratt, M. R.; Bertozzi, C. R. Chem. Soc. Rev. 2005, 34, 58-68. doi:10.1039/b400593g

3. Prescher, J. A.; Dube, D. H.; Bertozzi, C. R. Nature 2004, 430, 873-877. doi:10.1038/nature02791

4. Kolb, H. C.; Finn, M. G.; Sharpless, K. B. Angew. Chem., Int. Ed. 2001 , 40, 2004-2021. doi:10.1002/1521-3773(20010601)40:11<2004::AID-ANIE2004>3.0.CO ;2-5

5. Woycechowsky, K. J.; Raines, R. T. Curr. Opin. Chem. Biol. 2000, 4, 533-539. doi:10.1016/\$1367-5931(00)00128-9

6. Oae, S. Organic Sulfur Chemistry, Structure and Mechanism; CRC Press: Boca Raton, FL, 1991.

7. Cremlyn, R. J. An Introduction to Organosulfur Chemistry; John Wiley and Sons: New York, 1996.

8. Jocelyn, D. C. Biochemistry of the Thiol Groups; Academic Press: New York, 1992

9. Bhar, D.; Chandrasekaran, S. Synthesis 1994, 785-786 doi:10.1055/s-1994-25573

10. Tankam, T.; Poochampa, K.; Vilaivan, T.; Sukwattanasinitt, M.; Wacharasindhu, S. Tetrahedron 2016, 72, 788-793. doi:10.1016/j.tet.2015.12.036
11. Barba, F.; Ranz, F.; Batanero, B. Tetrahedron Lett. 2009, 50, 6798-6799. doi:10.1016/j.tetlet.2009.09.102

12. Ravelli, D.; Fagnoni, M.; Albini, A. Chem. Soc. Rev. 2013, 42, 97-113. doi:10.1039/C2CS35250H

13. Lang, X.; Chen, X.; Zhao, J. Chem. Soc. Rev. 2014, 43, 473-486. doi:10.1039/C3CS60188A

14. Hari, D. P.; König, B. Angew. Chem., Int. Ed. 2013, 52, 4734-4743. doi:10.1002/anie.201210276

15. Hofmann, J.; Heinrich, M. R. Tetrahedron Lett. 2016, 57, 4334-4340. doi:10.1016/j.tetlet.2016.08.034

16. Qin, H.-L.; Zheng, Q.; Bare, G. A. L.; Wu, P.; Sharpless, K. B. Angew. Chem., Int. Ed. 2016, 55, 14155-14158. doi:10.1002/anie.201608807

17. Arisawa, M.; Tanaka, K.; Yamaguchi, M. Tetrahedron Lett. 2005, 46, 4797-4800. doi:10.1016/j.tetlet.2005.05.024

18. Zysman-Colman, E.; Harpp, D. N. J. Org. Chem. 2003, 68, 2487-2489 doi:10.1021/jo0265481

19. Prier, C. K.; Rankic, D. A.; MacMillan, D. W. C. Chem. Rev. 2013, 113 5322-5363. doi:10.1021/cr300503r

20. Horspool, W. M.; Lenci, F. CRC Handbook of Organic Photochemistry and Photobiology, 2nd ed.; CRC press: Boca Raton, 2003; Vol. 1 \& 2.

21. He, L.; Qiu, G.; Gao, Y.; Wu, J. Org. Biomol. Chem. 2014, 12, 6965-6971. doi:10.1039/C4OB01286K

22. Xue, D.; Jia, Z.-H.; Zhao, C.-J.; Zhang, Y.-Y.; Wang, C.; Xiao, J. Chem. - Eur. J. 2014, 20, 2960-2965. doi:10.1002/chem.201304120

23. Dedeian, K.; Djurovich, P. I.; Garces, F. O.; Carlson, G.; Watts, R. J. Inorg. Chem. 1991, 30, 1685-1687. doi:10.1021/ic00008a003

24. Slinker, J. D.; Gorodetsky, A. A.; Lowry, M. S.; Wang, J.; Parker, S.; Rohl, R.; Bernhard, S.; Malliaras, G. G. J. Am. Chem. Soc. 2004, 126, 2763-2767. doi:10.1021/ja0345221

25. Schank, K.; Leider, R.; Lick, C.; Glock, R. Helv. Chim. Acta 2004, 87, 869-924. doi:10.1002/hlca.200490085

26. Carnell, A. J.; Johnstone, R. A. W.; Parsy, C. C.; Sanderson, W. R. Tetrahedron Lett. 1999, 40, 8029-8032. doi:10.1016/S0040-4039(99)01610-X 


\section{License and Terms}

This is an Open Access article under the terms of the Creative Commons Attribution License

(http://creativecommons.org/licenses/by/4.0), which permits unrestricted use, distribution, and reproduction in any medium, provided the original work is properly cited.

The license is subject to the Beilstein Journal of Organic Chemistry terms and conditions:

(http://www.beilstein-journals.org/bjoc)

The definitive version of this article is the electronic one which can be found at:

doi:10.3762/bjoc. 13.91 